\title{
Fluoride Release of Giomer and Resin Based Fissure Sealants
}

\section{Liberación de flúor de sellantes de fosas y fisuras a base de resina y/o ionómero}

\author{
Soner Şişmanoğlu DDS, PhD1
}

1. Department of Restorative Dentistry, Faculty of Dentistry, Altınbaş University, Istanbul, Turkey.

Correspondence to: Dr. Soner Şişmanoğlu - soner.s@hotmail.com

DOI: 10.15517/IJDS.V0I0.36860

ABSTRACT

Fissure sealants are applied to teeth to prevent caries development. The presence of the fissure sealant creates a protective barrier, which prevents plaque accumulation to the pits and fissure. They have a significant role in preventing pit and fissure caries. The aim of this study was to evaluate the time-dependent fluoride ion release of giomer- and resin-based fissure sealants. Fissure sealants were divided into 4 groups: BeautiSealant (Shofu, Japan), Clinpro Sealant (3M ESPE, USA), Helioseal F (Ivoclar Vivadent, Liechtenstein), Fissurit F (Voco, Germany). Disk shaped samples were prepared for each sealant material tested, and they were transferred into polyethylene vials containing $5 \mathrm{ml}$ of deionized water. Fluoride ion diffusion was determined on days $1,2,3,7,14,21$, and $28(n=7)$. The fluoride concentration in these samples was analyzed using a pre-calibrated spectrophotometer in parts per million (ppm). These experiments were performed in triplicates at room temperature. ANOVA and Tukey's HSD test were used for statistical analysis. BeautiSealant was released the highest amount of fluoride on day 1 (5.33 ppm), followed by a sudden decrease on the day $2(2.17 \mathrm{ppm})$. The burst effect was observed only in this group. Clinpro Sealant, Fissurit F and HelioSeal F groups presented fluoride release of 2.69, 2.94 and 2.91 ppm on the first day, respectively, without a significant difference ( $p>0.05$ ). After the first week, a constant fluoride release level has been reached. The fluoride release for the three resin-based fissure sealants was slightly lower than that for the giomer-based. After the first week, materials exhibited no significant difference and reached a plateau. The usage of a high and prolonged fluoride-releasing fissure sealant material should be considered by clinicians, particularly in patients with caries risk.

\section{KEYWORDS}

Fluoride; Fissure sealant; Composite resins; Dental materials. 


\section{RESUMEN}

Los sellantes de fosas y fisuras se utilizan con el objetivo de prevenir el desarrollo de caries. La presencia del sellante crea una barrera protectora, que evita la acumulación de placa en las fosas y fisuras. Tienen un papel importante en la prevención de la caries. El objetivo de este estudio fue evaluar la liberación de iones fluoruro de los sellantes de fosas y fisuras a base de lonómeros y resinas. Los sellantes de fosas y fisuras se dividieron en 4 grupos: BeautiSealant (Shofu, Japón), Clinpro Sealant (3M ESPE, EE. UU.), Helioseal F (Ivoclar Vivadent, Liechtenstein), Fissurit F (Voco, Alemania). Se prepararon muestras en forma de disco para cada material, y se transfirieron a viales de polietileno que contenían 5 $\mathrm{ml}$ de agua desionizada. La difusión de iones fluoruro se determinó en los días 1,2,3,7,14,21 y 28 ( $n=7)$. La concentración de fluoruro en estas muestras se analizó utilizando un espectrofotómetro precalibrado en partes por millón (ppm). Estos experimentos se realizaron por triplicado a temperatura ambiente. ANOVA y la prueba de HSD de Tukey se utilizaron para el análisis estadístico. BeautiSealant liberó la mayor cantidad de fluoruro en el día 1 (5.33 ppm), seguido por una disminución repentina en el día 2 (2.17ppm). Los grupos Clinpro Sealant, Fissurit F y HelioSeal F presentaron una liberación de fluoruro de 2.69, 2.94 y 2.91 ppm el primer día, respectivamente, sin una diferencia significativa ( $p>0.05)$. Posterior a la primera semana, fue alcanzado un nivel constante de liberación de fluoruro. La liberación de flúor para los tres sellantes de fosas y fisuras a base de resina fue ligeramente inferior a la de los lonómeros. Después de la primera semana, los materiales no mostraron diferencias significativas. Los odontólogos deben considerar el uso de un material sellante de fosas y fisuras que promueva la liberación de flúor a lo largo del tiempo, especialmente en pacientes con riesgo de caries.

\section{PALABRAS CLAVE}

Flúor; Sellante de fosas y fisuras; Resinas compuestas; Materiales dentales.

\section{INTRODUCTION}

Fissure sealant materials are applied to teeth that are prone to decay to prevent caries development $(1,2)$. The presence of the fissure sealant creates a protective barrier, which prevents plaque accumulation to pits and fissures (1-3). Their anticariogenic effects have been proven by many studies (1-3). In addition, Kramer et al. reported that glass-ionomer cement (GIC) and resin-modified GIC materials inhibit the formation of secondary caries in vitro (4). Current fissure sealants can be classified as resin-based, polyacid modified composite resin-based or glass-ionomerbased (5).

It is thought that glass-ionomer-based fissure sealant materials prevent the caries formation, and it is recommended that they could be applied especially to high caries risk patients $(2,6-8)$. The major disadvantage of glass-ionomerbased fissure sealants are their inadequate retention $(2,8,9)$, and inferior mechanical properties (10) than resin-based sealants. Hence, light-cured resin-based fissure sealants are often preferred due to their advantages such as ease of application, high retention rate and proven cariostatic effects $(2,9,11,12)$.

Decrease in caries incidence over the past years has been mostly related to the prevalent usage of fluoride in dentistry (6). Fluoride is known as anticariogenic and incorporated into various dental materials. In addition, fluoride-releasing materials, which attracted the interest of researchers, are continuously developing $(7,8)$. The amount of 
fluoride release, which prevents demineralization and promotes remineralization is not known exactly $(9,11,12)$. However, it is recommended to use materials with a prolonged fluoride release, since the presence of fluoride in saliva and dental biofilm reduces the enamel solubility $(13,14)$.

The material BeautiSealant (giomer) consists of surface pre-reacted glass-ionomer (S-PRG) filler particles. The acid base reaction resulting from water absorption of glass-ionomer-based materials and subsequent fluoride release also negatively affect the physical properties of the material. In giomers, fluoridated glass filler particles react with polyacrylic acid in an acid base reaction in the presence of water before being incorporated into the resin materials. Therefore, the type of setting reaction in giomer is different from the compomers, in which the reaction between the glass and the acid occurs when water is taken up by the restorative material $(15,16)$. The fluoride release capability of giomer material was reported to be lower in comparison to compomer (17). However, in a different study, compomer and giomer showed the similar fluoride release capability (18). The giomers can exhibit superiority to other resin-based fissure sealants with the relatively high fluoride release.

The fissure sealants have a significant role in prevention of pit and fissure caries, and studies on the fluoride release from different types of fissure sealant materials are required. Therefore, the aim of this in vitro study is to evaluate the fluoride release of varying types of fissure sealant materials. The null hypotheses of this in vitro study are 1) there would be no significant difference in the fluoride ion release of the sealant materials tested and 2) there would be no time-dependent changes in the fluoride ion release.

\section{MATERIALS AND METHODS}

Three resin-based, and one giomer-based fissure sealant materials were evaluated in this study. Sealants were used in accordance with the manufacturers' instructions. The compositions and manufacturers of the employed materials are given in Table 1. Fissure sealants were divided into 4 groups: BeautiSealant (Shofu, Japan), Clinpro Sealant (3M ESPE, USA), Helioseal F (Ivoclar Vivadent, Liechtenstein), Fissurit F (Voco, Germany).

Disk shaped samples were prepared for each sealant material tested. The specimens were loaded into a standard Teflon $®$ mold (5 $\mathrm{mm}$ diameter, $2 \mathrm{~mm}$ thickness), and then pressed between two opposing polyethylene strips. They were also covered with a microscope glass to extrude the excess material and obtain a smooth surface. All specimens were light cured (1750 $\mathrm{mW} / \mathrm{cm} 2$, Elipar Deep Cure, 3M ESPE) according to manufacturers' instructions. The samples were transferred into polyethylene vials with $5 \mathrm{ml}$ of deionized water. Seven containers were used for each material group $(n=7)$. The samples were stored at $37^{\circ} \mathrm{C}$ for 28 days. 
Table 1. Materials used.

\begin{tabular}{|c|c|c|}
\hline Materials & Type & Composition \\
\hline $\begin{array}{l}\text { BeautiSealant } \\
\text { Shofu, Kyoto, Japan. }\end{array}$ & Giomer-based & $\begin{array}{l}\text { Primer: Acetone, phosphoric acid monomer, carboxylic acid monomer, } \\
\text { distilled water. } \\
\text { Sealant: S-PRG fillers ( } 30 \% \text { by weight), micro fumed silica, UDMA, } \\
\text { TEGDMA. }\end{array}$ \\
\hline $\begin{array}{l}\text { Clinpro Sealant } \\
\text { 3M ESPE, St. Paul, MN, USA. }\end{array}$ & Resin-based & $\begin{array}{l}\text { Bis-GMA, TEGDMA, silane, Tetrabutylammonium tetrafluoroborate, } \\
\text { diphenyl Hexafluorophosphate, EDMAB, titanium hydroxide, } \\
\text { hydroquinone. Filler content is } 6 \% \text {. }\end{array}$ \\
\hline $\begin{array}{l}\text { HelioSeal F } \\
\text { Ivoclar Vivadent, Liechtenstein }\end{array}$ & Resin-based & $\begin{array}{l}\text { Monomer matrix: BIS-GMA (11.8\%), urethan dimethacrylate }(23.4 \%) \text {, } \\
\text { triethylene glycol dimethacrylate }(23.4 \%) \text {. } \\
\text { Fillers: Fluorosilicate glass }(20.3 \%) \text {, highly dispersed silicon dioxide } \\
(20.2 \%) \text {. Pigments, initiators. }\end{array}$ \\
\hline $\begin{array}{l}\text { Fissurit F } \\
\text { Voco, GmbH, Cuxhaven, Germany. }\end{array}$ & Resin-based & $\begin{array}{l}\text { Monomer matrix: Methacrylic acid ester (BIS-GMA), urethane } \\
\text { dimethacrylate (content } 91 \% \text { ). } \\
\text { Fillers: Borosilicate glass, NaF; } 3 \% \text { corresponds to } 1.3 \% \text { fluoride } \\
\text { content. }\end{array}$ \\
\hline
\end{tabular}

Abbreviations: Bis-GMA: Bisphenol A-glycidyl methacrylate, EDMAB: Ethyl 4-(dimethylamino)benzoate, TEGDMA: Triethylene glycol dimethacrylate, UDMA: Urethane dimethacrylate.

The fluoride ion concentration in these samples was analyzed using a pre-calibrated spectrophotometer (Thermo Scientific Evolution 160 UV-VIS, Germany) at $620 \mathrm{~nm}$ and the respective analysis kit (Spectroquant $\circledast$ fluoride test 114598 , Merck Millipore) allowing the determination in the concentration range of 0.1 to $20 \mathrm{mg} / \mathrm{L}$. At the time of readings, the containers were kept at room temperature $\left(25 \pm 1^{\circ} \mathrm{C}\right)$ and well-shaken. Fluoride ion diffusion was determined on days $1,2,3,7,14$, 21 , and $28,(n=7)$ which is compatible with the time intervals used in other studies [13]. Deionized water was used as a control. These experiments were performed in triplicates. The values obtained were then recorded.

The mean and standard deviation values of each experimental group were calculated. GraphPad Prism version 8 statistical software program was used for the statistical analysis. One-way analysis of variance (ANOVA) was used to compare the mean values between materials on each day, and two-way repeated measures ANOVA was used to determine the mean values of each material between measurement days. Multiple comparisons were carried out using Tukey's HSD test. Level of significance was set at 0.05.

\section{RESULTS}

Mean and standard deviations indicating the fluoride ion release of the sealant materials were determined on the days $1,2,3,7,14,21$, and 28. The comparisons of the mean values for measurement days are provided in Table 2. Figure 1-4 present the fluoride ions released for each sealant evaluated versus storage time. After a statistically significant difference noticed with respect to the concentration of fluoride ion release, Tukey HSD multiple comparisons were examined. Differences were observed in relation with time. Higher concentration release of fluoride ions was observed on day 1 for all materials. The giomerbased material (BeautiSealant) was the sealant material with the highest fluoride ion release on day 1 (5.33ppm), followed by a sudden decrease on the day 2 (2.17 ppm) and day 3 (1.85ppm), and this gradual decrease continued to a constant level of fluoride ion release. An initial "burst effect" was observed only in this group. Clinpro Sealant, 
Fissurit $F$ and HelioSeal $F$ groups presented fluoride ion release of 2.69, 2.94 and $2.91 \mathrm{ppm}$ on the first day, respectively with no significant difference $(p>0.05)$.

Between all measurements, the biggest fluoride ion release was observed in the BeautiSealant and on the first two days, and this difference was statistically significant $(p<0.05)$. Besides, no statistically significant difference was found between all material groups in subsequent measurements $(p>0.05)$. Furthermore, no significant difference was detected between the materials in the measurements performed on the 7th day and after. In other words, after the first week, a constant fluoride ion release level has been reached.

Table 2. The mean \pm SD (standard deviation) of fluoride-releasing sealant materials (ppm).

\begin{tabular}{|c|c|c|c|c|}
\hline & BeautiSealant & Clinpro Sealant & HelioSeal F & Fissurit F \\
\hline 1 & $5.33 \pm 0.67 \mathrm{a}, \mathrm{A}$ & $2,69 \pm 0,43$ a & $2,91 \pm 0,64{ }^{a}, \mathrm{~B}$ & $2,94 \pm 0,67$ а \\
\hline 2 & $2.17 \pm 0.27$ bd,$A$ & $2,90 \pm 0,22$ а & $2,84 \pm 0,38^{a}{ }^{a}{ }^{B}$ & $2,90 \pm 0,16$ a \\
\hline 3 & $1.85 \pm 0.28 \mathrm{~b}, \mathrm{~A}$ & $1,86 \pm 0,30 \mathrm{~b}, \mathrm{~A}$ & $2,00 \pm 0,24 \mathrm{~b}, \mathrm{~A}$ & $2,15 \pm 0,08 \mathrm{~b}, \mathrm{~A}$ \\
\hline 7 & $1.59 \pm 0,21 \mathrm{~cd}, \mathrm{~A}$ & $1,11 \pm 0,07 \mathrm{c}, \mathrm{A}$ & $1,25 \pm 0,16^{\mathrm{c}, \mathrm{A}}$ & $1,26 \pm 0,04{ }^{\mathrm{c}, \mathrm{A}}$ \\
\hline 14 & $1.29 \pm 0,06^{\mathrm{c}, \mathrm{A}}$ & $1,07 \pm 0,09 \mathrm{c}, \mathrm{A}$ & $1,22 \pm 0,07 \mathrm{c}, \mathrm{A}$ & $1,15 \pm 0,08^{c}, A$ \\
\hline 21 & $1.16 \pm 0,02{ }^{\mathrm{c}, \mathrm{A}}$ & $0,96 \pm 0,04^{\mathrm{c}, \mathrm{A}}$ & $1,24 \pm 0,03{ }^{c}, \mathrm{~A}$ & $1,18 \pm 0,01{ }^{c}, A$ \\
\hline 28 & $1.12 \pm 0,02 \mathrm{c} \mathrm{A}$ & $1,00 \pm 0,06 \mathrm{c} A$ & $1,01 \pm 0,03 \mathrm{cA}$ & $1,21 \pm 0,03 \mathrm{c} \mathrm{A}$ \\
\hline
\end{tabular}

Same lower-case superscript letter within a column and same uppercase superscript letter within a row for each day signifies no significant difference, according to Tukey HSD test ( $p>0.05)$.

\section{DISCUSSION}

Studies suggested that fluoride incorporated fissure sealants significantly reduced the amount of demineralization compared to non-fluoridated fissure sealants (19-21). Numerous studies have been carried out on the fluoride release patterns of glass-ionomer-based fissure sealant materials $(18,22,23)$. However, the number of researches was done on the fluoride release pattern of resinbased and giomer-based fissure sealants are inadequate. All fissure sealant materials in the present study released varying amount of fluoride. This difference in fluoride releases may be due to the chemical composition of the materials. On the other hand, the highest fluoride release was observed in the fissure sealant which is giomerbased (BeautiSealant, 5.33ppm). Furthermore, fluoride release of all fissure sealant materials was decreased with time. After the first week, they all showed a constant fluoride release level of fluoride. Therefore, both null hypotheses were rejected.

Various media such as acidic media (24), artificial saliva (25) and deionized water can be preferred to determine fluoride release of restorative materials. Since no ion is present in deionized water, it is thought that fluoride release can be estimated more precisely. This idea is accepted by many researchers $(17,18)$. Therefore, deionized water was preferred to be compatible with other studies in our study protocol. On the other hand, the fluoride ion release stops when equilibrium is achieved due to the concentration gradient mechanism (26). Therefore, as suggested by other researchers, medium was changed at 24hour intervals (27-29). The fluoride ion release is a complicated mechanism affected by intrinsic and extrinsic factors, such as material solubility, composition, powder-liquid ratio, surface area 
of the specimen, and the environment $(30,31)$. The amount of fluoride release, which prevents demineralization and promotes remineralization is not known exactly. In some studies, this amount is reported to be between 0.02 and $0.06 \mathrm{ppm}$ (32). However, it is preferable to use materials with the high and prolonged fluoride ion release, since the fluoride ion presence in oral cavity reduces the enamel solubility $(13,14)$. According to the results of our study, resin-based sealant materials produced a fluoride release of approximately 2.5 to 3 ppm on the first day, which was approximately half of the giomer-based sealant. The amounts of fluoride release decreased with time and remained at about 1-1.5 ppm after the 7th day and remained unchanged until the end of 4 th week.

Studies have shown that the fluoride release occurs rapidly and most of the release occurs in the first two days $(10,18,33)$. In particular, this initial release occurs in the first 24-hour period and called as "burst effect". Subsequently, a significant reduction in the amount of fluoride release takes place. Especially after the second week, the daily fluoride release reaches a plateau and no change is observed day by day $(10,18,33)$. In our study, similar results were obtained with other studies. The fluoride release of all fissure sealants showed a statistically significant decrease after the second day. In the giomer-based fissure sealant material, a glass-ionomer-like "burst effect" was observed. The amount of fluoride release on the first day (5.33ppm) was about twice that of the fluoride release at the end of the second day $(2.17 \mathrm{ppm})$. Furthermore, after the first week, a constant fluoride release level of fluoride has been reached.

BeautiSealant consist of a glass-ionomer matrix filled with fluorinated glass. A giomer using the pre-reacted glass-ionomer filler technology, wherein only the surface of the fluorinated glass fillers reacts with polyacrylic acid. It has been noted that the fluoride release from the giomers is higher than the composite resins, but lower than the glass-ionomer-based materials $(15,18)$. The results exhibited by BeautiSealant in this study were in an agreement with these findings.

In a study, fluoride ion release from Clinpro Sealant, Fissurit $F$ and HelioSeal $F$ were evaluated at a time-dependent manner and as a result 2.54, 26.0, 6.57 ppm values were obtained, respectively (34). The first day measurement values obtained from this study did not match the results of our study. It can be thought that this difference is due to the difference in sample preparation. In accordance with our study, Salmeron-Valdes et al. (34) reported that giomer-based sealant material has a fluoride release higher than resin-based sealant materials. In addition, they observed a decrease in fluoride release values after the second day, similar in our study.

In another study, researchers compared fluoride release of several dental materials, among which there were two resin-based fissure sealants, which were Fissurit $F$ and HelioSeal F. They observed that on the 1st day Fissurit $F$, with $0.236 p p m$, and HelioSeal F, with 0.230 ppm. They also reported a nonsignificant difference between their fluoride releases (20). These findings are also consistent with our results. In our study, we did not observe any significant difference between resinbased sealants with regard to fluoride release.

\section{CONCLUSION}

In the current in vitro study, all giomer- and resin-based fissure sealants exhibited an extensive fluoride ion release in the first two days, which was followed by a significant drop. The amount of fluoride ion released in vitro for the three resinbased fissure sealants was slightly lower than that for the giomer-based on the first day. After the first week, both the giomer- and resin-based sealants exhibited no significant difference and reached a plateau. The usage of a high and prolonged fluoride releasing fissure sealant material should 
be considered by the clinicians, particularly in patients with caries risk. Longer-term clinical trials on fluoride release of resin-based fissure sealant materials are required.

\section{REFERENCES}

1. Mejàre I., Lingström P., Petersson L. G., Holm A., Twetman S., Källestål C., et al. Caries preventive effect of fissure sealants: a systematic review. Acta Odontol Scand. 2003; 61 (6): 321-30.

2. Ahovuo-Saloranta A., Hiiri A., Nordblad A., Mäkelä M., Worthington H. V. Pit and fissure sealants for preventing dental decay in the permanent teeth of children and adolescents. In: Ahovuo-Saloranta A, editor. Cochrane Database of Systematic Reviews. Chichester, UK: John Wiley \& Sons, Ltd; 2008. p. CD001830.

3. Simonsen R. J. Pit and fissure sealant: review of the literature. Pediatr Dent. 2002; 24 (5): 393-414.

4. Krämer N., Schmidt M., Lücker S., Domann E., Frankenberger R. Glass ionomer cement inhibits secondary caries in an in vitro biofilm model. Clin Oral Investig. 2018; 22 (2): 1019-31.

5. Kuşgöz A., Tüzüner T., Ulker M., Kemer B., Saray O. Conversion degree, microhardness, microleakage and fluoride release of different fissure sealants. J Mech Behav Biomed Mater. 2010; 3 (8): 594-9.

6. A. Alsaffar, D. Tantbirojn, A. Versluis, S. Beiraghi. Protective effect of pit and fissure sealants on demineralization of adjacent enamel. Pediatr Dent. 2011; 33 (7): 491-5.

7. Campus G., Carta G., Cagetti M. G., Bossù M., Sale S., Cocco F., et al. Fluoride concentration from dental sealants. J Dent Res. 2013; 92 (7): S23-8.

8. Ulusu T., Odabaş M. E., Tüzüner T., Baygin O., Sillelioğlu H., Deveci C., et al. The success rates of a glass ionomer cement and a resin-based fissure sealant placed by fifthyear undergraduate dental students. Eur Arch Paediatr Dent. 2012; 13 (2): 94-7.

9. Azarpazhooh A., Main P. A. Pit and fissure sealants in the prevention of dental caries in children and adolescents: a systematic review. J Can Dent Assoc. 2008; 74 (2): 171-7.

10. Kavaloglu Cildir S., Sandalli N. Compressive strength, surface roughness, fluoride release and recharge of four new fluoride-releasing fissure sealants. Dent Mater J. 2007; 26 (3): 335-41.

11. Poulsen S., Laurberg L., Vaeth M., Jensen U., Haubek D. A field trial of resin-based and glass-ionomer fissure sealants: clinical and radiographic assessment of caries. Community Dent Oral Epidemiol. 2006; 34 (1): 36-40.

12. Muller-Bolla M., Lupi-Pégurier L., Tardieu C., Velly A. M., Antomarchi C. Retention of resin-based pit and fissure sealants: A systematic review. Community Dent Oral Epidemiol. 2006; 34 (5): 321-36.

13. Petersson G. H., Bratthall D. The caries decline: a review of reviews. Eur J Oral Sci. 1996; 104 (4): 436-43.

14. Bahadure R., Pandey R., Kumar R., Gopal K., Singh R. An estimation of fluoride release from various dental restorative materials at different $\mathrm{pH}$ : In vitro study. J Indian Soc Pedod Prev Dent. 2012; 30 (2): 122.

15. Naoum Ellakwa F. Martin M. Swain S. A., Naoum S., Dip G., Ellakwa A., Elizabeth Martin F., Swain M. Fluoride release, recharge and mechanical property stability of various fluoride-containing resin composites. 2011; 36 (4): 422-32.

16. Dionysopoulos D., Koliniotou-Koumpia E., Helvatzoglou-Antoniades M., Kotsanos N. Fluoride release and recharge abilities of contemporary fluoride-containing restorative materials and dental adhesives. Dent Mater J. 2013; 32 (2): 296-304.

17. Mousavinasab S. M., Meyers I. Fluoride release by glass ionomer cements, compomer 
and giomer. Dent Res J (Isfahan). 2009; 6 (2): 75-81.

18. Bayrak G. D., Sandalli N., Selvi-Kuvvetli S., Topcuoglu N., Kulekci G. Effect of two different polishing systems on fluoride release, surface roughness and bacterial adhesion of newly developed restorative materials. J Esthet Restor Dent. 2017; 29 (6): 424-34.

19. Garcia-Godoy F., Abarzua I., De Goes M. F., Chan D. C. Fluoride release from fissure sealants. J Clin Pediatr Dent. 1997; 22 (1): 45-9.

20. Helvatjoglu-Antoniades M., Karantakis P., Papadogiannis Y., Kapetanios H. Fluoride release from restorative materials and a luting cement. J Prosthet Dent. 2001; 86 (2): 156-64.

21. de Araujo F. B., García-Godoy F., Cury J. A., Conceição E. N. Fluoride release from fluoride-containing materials. Oper Dent. 1996; 21 (5): 185-90.

22. Yamazaki H., Litman A., Margolis H. C. Effect of fluoride on artificial caries lesion progression and repair in human enamel: Regulation of mineral deposition and dissolution under in vivo-like conditions. Arch Oral Biol. 2007; 52 (2): 110-20.

23. Hellwig E., Lennon Á. M. Systemic versus topical fluoride. Caries Res. 2004; 38 (3): 258-62.

24. Karantakis P., Helvatjoglou-Antoniades M., Theodoridou-Pahini S., Papadogiannis Y. Fluoride release from three glass ionomers, a compomer, and a composite resin in water, artificial saliva, and lactic acid. Oper Dent. 2000; 25 (1): 20-5.

25. Preston A. J., Mair L. H., Agalamanyi E. A., Higham S. M. Fluoride release from aesthetic dental materials. J Oral Rehabil. 1999; 26 (2): 123-9.
26. Lee S. Y., Dong D. R., Huang H. M., Shih Y. H. Fluoride ion diffusion from a glassionomer cement. J Oral Rehabil. 2000; 27 (7): 576-86.

27. Neelakantan P., John S., Anand S., Sureshbabu N., Subbarao C. Fluoride release from a new glass-ionomer cement. Oper Dent. 2011; 36 (1): 80-5.

28. Strother J. M., Kohn D. H., Dennison J. B., Clarkson B. H. Fluoride release and re-uptake in direct tooth colored restorative materials. Dent Mater. 1998; 14 (2): 129-36.

29. Eliades G., Kakaboura A., Palaghias G. Acid-base reaction and fluoride release profiles in visible light-cured polyacid-modified composite restoratives (compomers). Dent Mater. 1998; 14 (1): 57-63.

30. Hicks M. J., Flaitz C. M., Garcia-Godoy F. Fluoride-releasing sealant and caries-like enamel lesion formation in vitro. J Clin Pediatr Dent. 2000; 24 (3): 215-9.

31. Jensen M. E., Wefel J. S., Triolo P. T., Hammesfahr P. D. Effects of a fluoridereleasing fissure sealant on artificial enamel caries. Am J Dent. 1990; 3 (2): 75-8.

32. Eichmiller F. C., Marjenhoff W. A. Fluoridereleasing dental restorative materials. Oper Dent. 1998; 23 (5): 218-28.

33. Paschoal M. A. B., Gurgel C. V., Rios D., Magalhães A. C., Buzalaf M. A. R., Machado M. A. de A. M. Fluoride release profile of a nanofilled resin-modified glass ionomer cement. Braz Dent J. 2011; 22 (4): 275-9.

34. Salmerón-Valdés E. N., Scougall-Vilchis R. J., Alanis-Tavira J., Morales-Luckie R. A. Comparative study of fluoride released and recharged from conventional pit and fissure sealants versus surface prereacted glass ionomer technology. J Conserv Dent. 2016; 19 (1): 41-5. 